Methyl bromide alternatives ...

\title{
Soil solarization provides weed control for limited-resource and organic growers in warmer climates
}

James J. Stapleton

Richard H. Molinar

Kris Lynn-Patterson

Stuart K. McFeeters

Anil Shrestha

Organic farmers and limited-resource growers in the San Joaquin Valley and other agricultural areas in California - many of whom are ethnic minorities - encounter limited options and environmental constraints when seeking economically viable pest management methods. Over the past 8 years, we have conducted weed research and implementation projects on soil solarization at the UC Kearney Research and Extension Center and on farms in the surrounding San Joaquin Valley. In the Kearney studies, small-scale solarization in parsley reduced weed biomass 94\% to $99 \%$ over the untreated control. Furthermore, in an on-farm study, solarization provided effective weed control for strawberries at a much lower cost than methyl bromide, with comparable yields. This research has provided guidelines and technical support for growers wishing to implement solarization and related techniques for nonchemical soil disinfestation in a wide variety of specialty crops.

$\mathrm{M}$ ore than $80 \%$ of California farms are small family operations, making less than $\$ 250,000$ in annual gross income, according to the U.S. Department of Agriculture's definition. Of these, $85 \%$ gross less than $\$ 100,000$ annually. Classified as limited-resource farms, these comprise $72 \%$ of all California farms. To survive economically, small farms

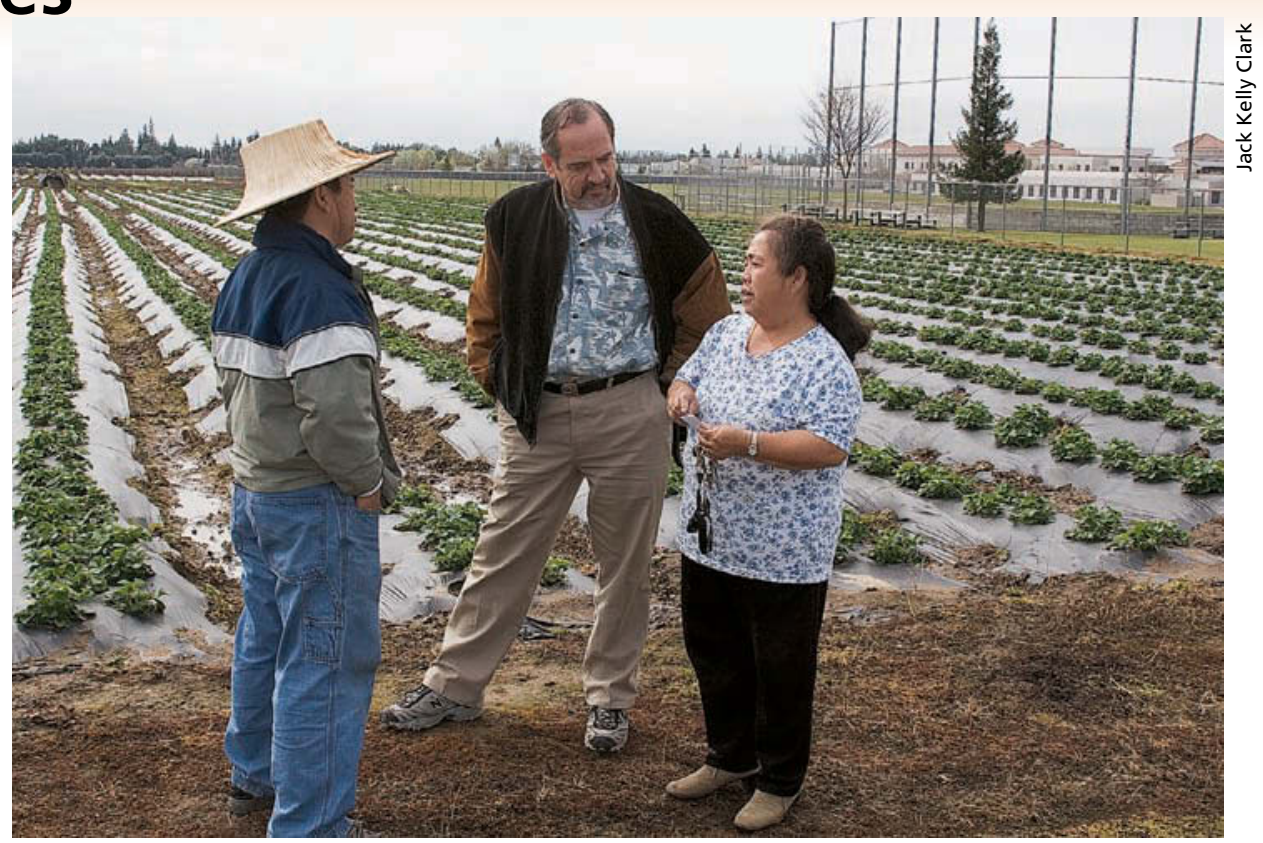

Soil solarization is a "perfect fit" for small-scale specialty crop growers like Ong Lee Yang (right), according to Richard Molinar, Fresno County small farms advisor (middle). Central Valley strawberry growers can take advantage of hot summers to tarp their fields in July and August between production cycles. Interpreting for the Hmong farmer is Michael Yang (left), a UC small farms program representative.

must depend on high-value specialty crops, specialized marketing programs or specific market windows. In many San Joaquin Valley counties, minorities, including Asians, Latinos, blacks, American Indians and others, operate almost $50 \%$ of the small farms. Fresno County's farmers are more diverse than those in any other California county, with a large proportion of Asian and Latino farmers. The Asian farmers are primarily Hmong, Lao and other groups that have emigrated to the United States since 1979. Although the total number of small farms in California decreased by 9.5\% between 1997 and 2002, the number of minority farm operators increased by $52 \%$ (USDA 2004), with the largest proportional increases in Latinos (65\%) and American Indians (70\%).

Although only about $2.5 \%$ of all California small farms are registered organic, statewide farmland in production for the organic market totals more than 175,000 acres (CDFA 2002). Limitedresource growers and organic farmers in the San Joaquin Valley and other agricultural areas confront limited choices and environmental constraints when seeking economically viable pest management options. Many specialty crops have few labeled pesticides, due to the high development and support costs and low returns for the manufacturers. Organic growers are at an additional disadvantage due to the restrictions on pesticides allowable under organic certification programs. Also, many of the farms are located at the urbanagricultural interface, and the use of pesticides and fumigants is further restricted in fields close to occupied buildings. In general, weed management is the most pervasive problem for San Joaquin Valley specialty crop and organic growers.

Strawberries have been an important specialty crop for San Joaquin Valley small farmers, with the majority of the acreage located in Fresno and Merced counties. The Fresno County Agricultural Commissioner reported 137 acres of strawberries worth nearly 


\section{All of the solarization treatments were equally effective in providing weed management, with weed numbers reduced by $86 \%$ to $94 \%$ and weed biomass reduced by $94 \%$ to $99 \%$ over the untreated control.}

$\$ 1.5$ million in 2002, albeit less than $1 \%$ of the statewide total. The cultivation of strawberries in the San Joaquin and Sacramento valleys is quite different from that of the major strawberry production areas along the California coast, with a short, split, fall-spring harvest season and most fruit destined for processing and roadside sales, rather than fresh-market shipping. Most San Joaquin Valley strawberry farmers are Hmong immigrants who produce much of the crop at the urban-agricultural interface, often on rented land in close proximity to occupied buildings.

Historically, most strawberry fields in the San Joaquin Valley are fumigated every 2 to 3 years, depending on weed pressure and the availability of funds, while coastal plantings are usually fumigated every year. However, many of the strawberry fields in the San Joaquin Valley are close to shopping centers and residential homes, so growers may find fumigation impractical. Pesticide regulations require that growers maintain buffer zones between fumigation areas and occupied dwellings (Carter et al. 2005).

Also, while most fumigations in the past were done with methyl bromide/ chloropicrin, the regulatory phase-out of methyl bromide has increased the cost of the remaining supply to the point of being prohibitive. In 2003, many San Joaquin Valley strawberry fields were fumigated with metam sodium, a moderately effective alternative fumigant that is significantly less expensive than methyl bromide (Richard Molinar, UC Farm Advisor, personal communication).

An alternative to chemical fumigation is soil solarization, a hydrothermal soil-disinfestation process that utilizes clear plastic mulch to trap solar radiation in moist soil. Solarization during the hot summer months can increase soil temperatures to levels that can kill soilborne disease, nematodes and weeds (Elmore et al. 1993). As with methyl bromide, plants often grow faster and produce higher yields when grown in solarized soil, as a result of weed and disease control, the increased solubility of nutrients, and changes in the microbial composition of the soil (Stapleton, Elmore, et al. 2000). Soil solarization can be a safe and effective method for controlling soil pests, and its effectiveness can be improved by combining it with other treatments such as fertilizers, cruciferous crops and other chemical treatments including metam sodium.

In this report, we describe solarization technology for weed management. This project, conducted at the UC Kearney Research and Extension Center (KREC) over the past 8 years, consisted of laboratory development, small-plot experimentation and on-farm validation of data in San Joaquin Valley specialty crops.

\section{Preliminary laboratory studies}

As a first step, earlier laboratory work done at KREC from 1997 to 1999 developed threshold treatment dosages for estimating weed management by soil heating (Stapleton, Prather, et al. 2000). In a series of experiments, we subjected the seed of six important weed species - barnyardgrass (Echinochloa crus-galli), London rocket (Sisymbrium irio), common purslane (Portulaca oleracea), black nightshade (Solanum nigrum), annual sowthistle (Sonchus oleraceus) and tumble pigweed (Amaranthus albus) - to timed heat treatments at 102,108,114, 122, 140 and $158^{\circ} \mathrm{F}\left(39,42,46,50,60\right.$ and $\left.70^{\circ} \mathrm{C}\right)$. The weed species were selected to represent a range of thermal sensitivities and summer versus winter growing habits. Percentages of viability were determined 14 days after removal from the heat treatments.

At $158^{\circ} \mathrm{F}\left(70^{\circ} \mathrm{C}\right)$, the seeds of all species were dead within 20 minutes, and at
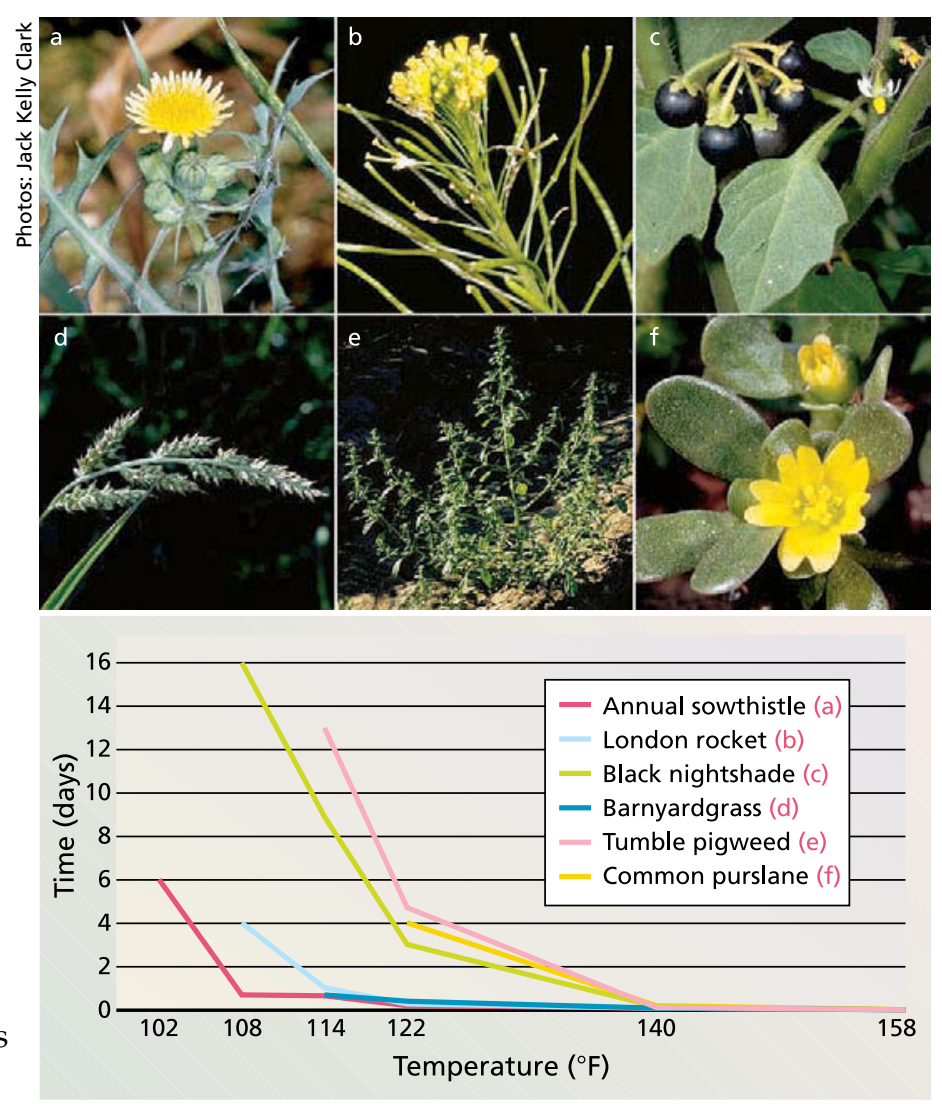

Fig. 1. Estimated lower threshold temperatures and times for isothermal inactivation of seed of six weed species from laboratory experiments (adapted from Stapleton, Prather, et al. 2000). 


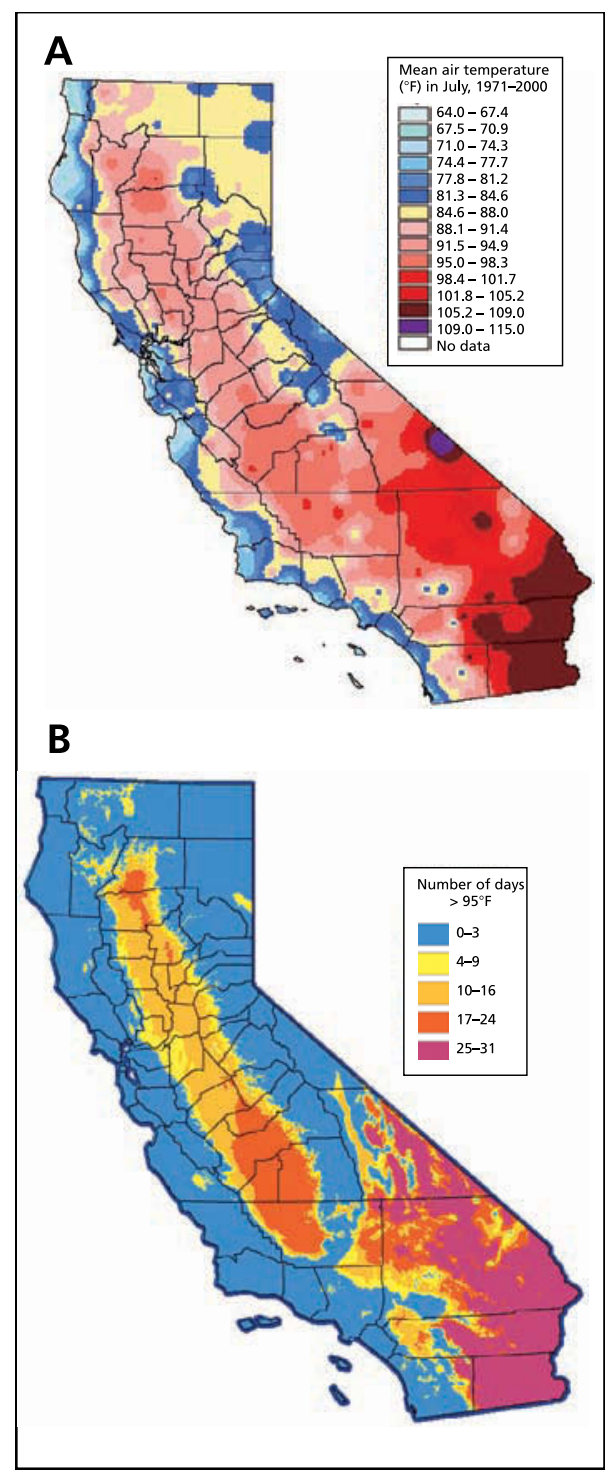

Fig. 2. Air-temperature maps of California in July, showing (A) mean daily maxima (30-year average); and (B) mean number of days in the month with maxima greater than or equal to $95^{\circ} \mathrm{F}$ (10-year average). Raw data source: $\mathrm{Na}$ tional Climatic Center, NOAA.

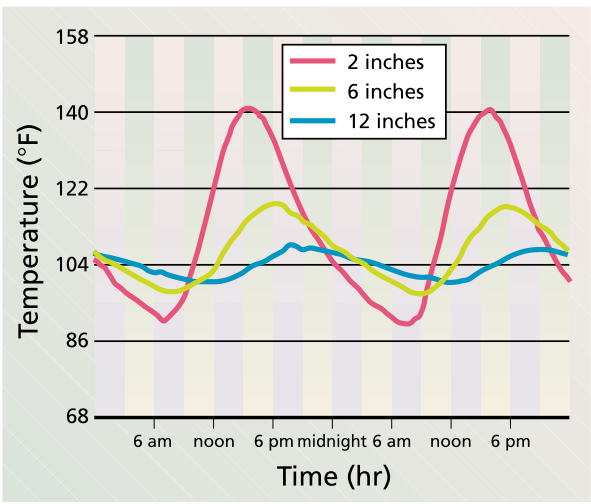

Fig. 3. Typical diurnal soil-temperature curves during solarization in the San Joaquin Valley, at three depths.

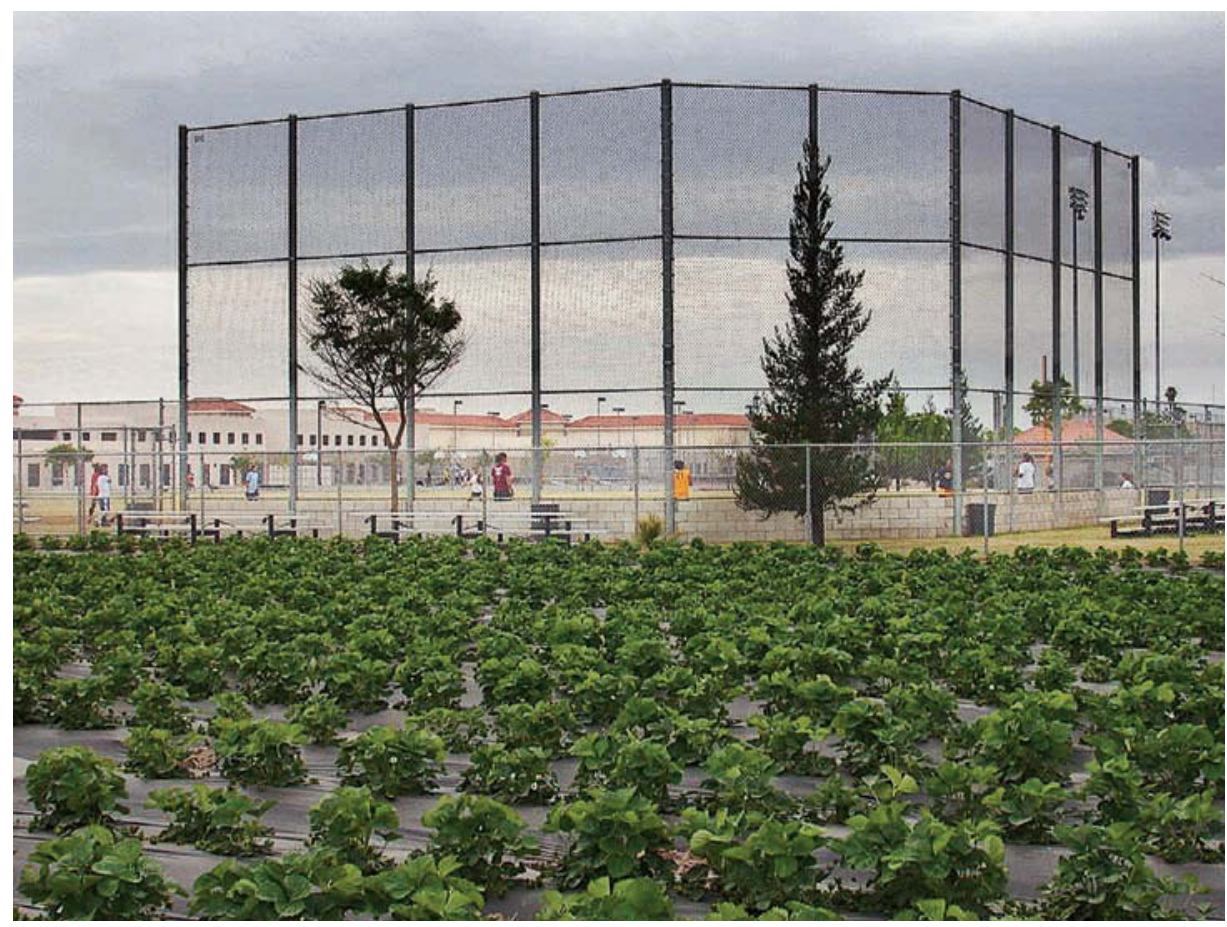

One of the challenges facing many small-scale farmers in California is their close proximity to urban areas. This strawberry field is adjacent to a baseball field at Sunnyside High School in Fresno. Solarization affords a safe, nonchemical alternative for dealing with certain pest problems.

$140^{\circ} \mathrm{F}\left(60^{\circ} \mathrm{C}\right)$ all species were dead within 3 hours. At $122^{\circ} \mathrm{F}\left(50^{\circ} \mathrm{C}\right)$, complete seed destruction occurred between 4 hours (annual sowthistle) and 4.7 days (tumble pigweed). At $114^{\circ} \mathrm{F}\left(46^{\circ} \mathrm{C}\right)$, thermal death occurred at a range of 15 hours (annual sowthistle) to 13 days (tumble pigweed). At $108^{\circ} \mathrm{F}\left(42^{\circ} \mathrm{C}\right)$, barnyardgrass, tumble pigweed and common purslane germinated inside the jars during the heat treatment. Barnyardgrass, tumble pigweed and common purslane were not studied at $102^{\circ} \mathrm{F}\left(39^{\circ} \mathrm{C}\right)$, since $108^{\circ} \mathrm{F}$ $\left(42^{\circ} \mathrm{C}\right)$ had no effect on their viability (fig. 1). Additionally, the portion of this laboratory study conducted at $140^{\circ} \mathrm{F}\left(60^{\circ} \mathrm{C}\right)$ and $158^{\circ} \mathrm{F}\left(70^{\circ} \mathrm{C}\right)$ was used to assist in developing guidelines for the weed disinfestation of container nursery soil using a specialized solarization technique (Stapleton et al. 2002).

\section{Developing guidelines using GIS}

Solarization is a knowledge-based, rather than product-based soil disinfestation method. As such, end users are largely without the benefit and availability of the trained consultants and product support personnel associated with chemical pesticides. Many growers, pest control advisors and gardeners are often unsure as to the suitability of solarization for their particular geographic locations. To facilitate decision-making, we collaborated with the Kearney Agricultural Center (KAC) Geographic Information Systems (GIS) unit to create statewide air-temperature maps, using historical temperature databases obtained from the National Oceanic and Atmospheric Administration's National Climatic Data Center. These maps include both monthly air-temperature maxima (fig. 2A), and mean number of days warmer than minimum thresholds $\left(\mathrm{a} 95^{\circ} \mathrm{F}\left[35^{\circ} \mathrm{C}\right]\right.$ minimum is depicted in fig. 2B), which can be accessed (www.uckac.edu/iwgss) by users who wish to estimate the suitability of their area for solarization.

Within the next few months, soil temperature models will be added to the Web site, to provide additional decision support for users (fig. 3). At the present time, however, users should conduct tests with soil thermometers or other temperature-sensing equipment to assess the potential for using solarization on their own land and for their particular climatic niches.

\section{Small-plot field studies}

Several small-plot studies were conducted at KREC to support the weedseed inactivation studies conducted in 


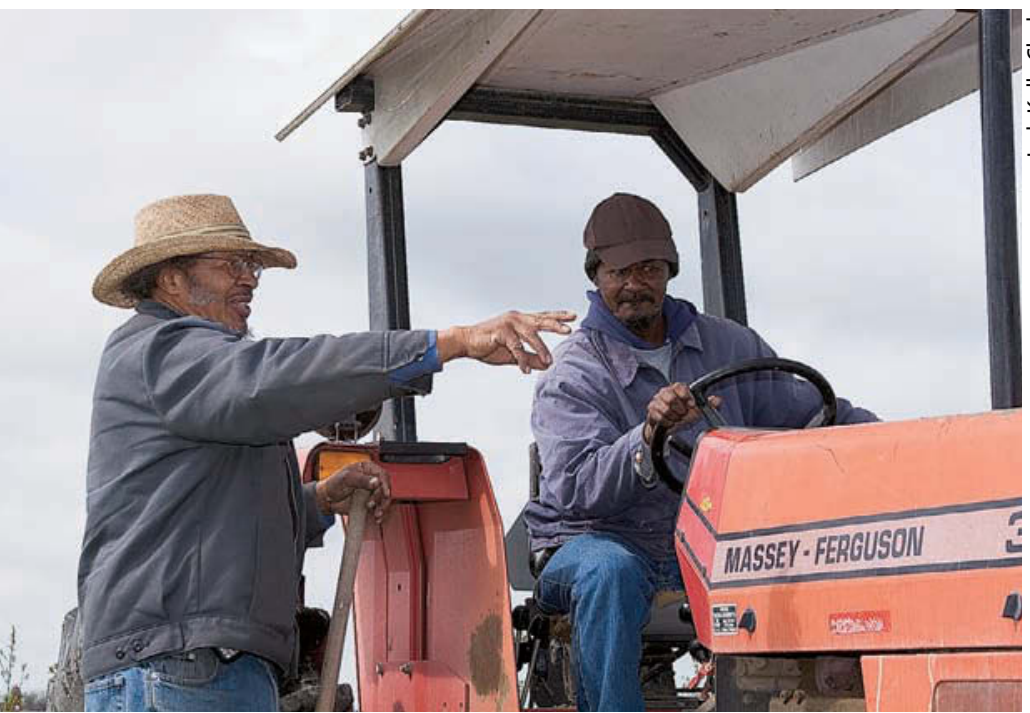

In 2002, more than 65 "minor" or specialty vegetable and fruit crops worth more than $\$ 75 \mathrm{mil}-$ lion were grown on 17,000 acres in Fresno County. Among the producers of those crops is Will Scott, Jr. (left) and his brother Melvin (on tractor), who grow turnips, peanuts, squash and other crops, and truck them to Oakland for sale at a local farmers market. Scott is working with Cooperative Extension in field trials to demonstrate solarization to fellow members of the African American Farmers Organization he helped found.
TABLE 2. Effects of soil solarization and fumigation treatments on weed management and marketable yield of strawberry, Clovis

\begin{tabular}{|c|c|c|c|}
\hline \multirow[b]{3}{*}{ Treatment* } & \multirow{2}{*}{\multicolumn{2}{|c|}{ Weed control }} & \multirow{3}{*}{$\begin{array}{c}\text { Strawberry yield } \\
\text { Marketable } \\
\text { fresh wt. }\end{array}$} \\
\hline & & & \\
\hline & Weeding rate & Weed density & \\
\hline & Person-min. 140 row ft. & number $/ m^{2}$ & kg/40 row ft. \\
\hline \multicolumn{4}{|l|}{ Experiment A } \\
\hline Metam sodium + solarized & 7.6at & $\mathrm{nd} \neq$ & 42.0 \\
\hline Solarized & $8.9 a$ & nd & 41.7 \\
\hline MBC (+ 14-day solarized) & $12.9 a$ & nd & 40.6 \\
\hline MBC (+ 5-day solarized) & $13.4 a$ & nd & 43.9 \\
\hline Metam sodium & $14.1 \mathrm{a}$ & nd & 40.5 \\
\hline Untreated control & $26.9 \mathrm{~b}$ & nd & 30.9 \\
\hline \multicolumn{3}{|l|}{ Experiment B§ } & kg/30 row ft. \\
\hline Solarized (+ mulch) & nd & $2.5 a$ & $36.5 a$ \\
\hline Metam sodium & nd & $2.0 a$ & $32.8 a b$ \\
\hline Solarized (- mulch) & nd & $1.3 a$ & $29.7 b$ \\
\hline Metam sodium + solarized & nd & $1.3 a$ & $28.4 b c$ \\
\hline Untreated control & nd & $41.5 b$ & $23.5 c$ \\
\hline \multicolumn{4}{|c|}{$\begin{array}{l}\text { * } \mathrm{MBC}=80 / 20 \text { methyl bromide/chloropicrin at } 300 \mathrm{lb} . \text { per acre; solarized = solarization } \\
\text { for } 4 \text { weeks (July 26-Aug. 26); metam sodium = Vapam ( } 42 \% \text { a.i. @ } 40 \text { gal./acre). }\end{array}$} \\
\hline \multicolumn{4}{|c|}{ † Values followed by different letters are statistically different (LSD test; $P<0.05$ ). } \\
\hline \multicolumn{4}{|l|}{$\ddagger$ nd $=$ no data collected. } \\
\hline \multicolumn{4}{|c|}{$\S$ Solarized = solarization for 4 weeks (Aug. 19-Sept. 18). } \\
\hline
\end{tabular}

12) plus solarization for 4 weeks; (5) metam sodium plus plastic left on only 48 hours; and (6) the untreated control. Soil moisture was applied by preirrigation. Strawberry (Fragaria $\times$ ananassa $\mathrm{cv}$. Chandler) plants were set out on Aug. 28 and drip-irrigated. Plant spacing down the row was 12 inches, and a standard fertilizer and insect management program was followed according to the grower's preferences. Yields were taken from 40 -foot lengths of the middle beds only.

The second experiment (B) also was located in a residential area, on Ramona sandy loam soil. The site had been fumigated with methyl bromide/ chloropicrin one season earlier. Bed spacing was 54 inches from center to center, and treatment plots were 30 feet long. Again, the plot was laid out as a randomized complete block, but with four replications of each treatment. Treatments were the same as in experiment $\mathrm{A}$, except that methyl bromide/chloropicrin fumigation was not included, and single-bed replications were used. Soil in planting beds was solarized for 4 weeks later in the year than in experiment A (Aug. 19 to Sept. 18, 1998) using clear, 1-mil $(0.025 \mathrm{~mm})$ polyethylene film. Metam sodium (Vapam; $42 \%$ a.i.) was applied in the same way as in experiment A. The film was left on the ground and plants transplanted through it after solarization in one of the treatments. Following the soil disinfestation treatments, 'Chandler' strawberry plants were set out on Sept. 18 at an in-row spacing of 12 inches, two rows per bed, and the fertilization and insect management practices of the grower were followed. Soil temperatures were monitored in both experiments, and the data collected included weed management parameters and marketable berry yields.

\section{Weeding costs, person hours}

Experiment A. All plots in experiment A were hand-weeded on four different dates (Oct. 6 and Nov. 10, 1997; Jan. 23 and Feb. 17, 1998), based on the weediness of the untreated control, which was moderate at the time of each weeding. The time taken to hand-weed a 40-foot-long strip of each replication was recorded and totaled. All treatments required $48 \%$ to $72 \%(P<$ 0.01 ) less time to weed than the untreated control (table 2). None of the costs for solarization and / or chemical fumigant treatment were different from each other. When the hand-weeding labor cost, estimated at $\$ 7.90$ per hour, was extrapolated to an entire field, use of the soil disinfestation treatments would have saved the grower $\$ 127$ (metam sodium alone) to $\$ 190$ (metam sodium plus solarization) per acre, compared to the control.
The same weeds that were comparatively resistant to chemical fumigation (cheeseweed [Malva parvifolia], burclover [Medicago sp.], Spanish clover [Lotus purshianus], red and white stem filaree [Erodium sp.] and birdsfoot trefoil [Lotus corniculata]) also were more tolerant of solarization. The weeds in the untreated control were much more variable, and included the above weeds plus shepherdspurse (Capsella bursapastoris), cudweed (Gnaphalium sp.), common chickweed, panicled willow herb (Epilobium brachycarpum), London rocket, annual bluegrass, puncturevine (Tribulus terrestris), prickly lettuce (Lactuca serriola) and crabgrass (Digitaria sp.).

Experiment B. As only a single season had passed after the previous soil fumigation with methyl bromide, weed growth was relatively light in experiment B, even in the untreated controls. For this reason, timed hand-weedings were not made, and weediness in the experimental plots was expressed as the number of weeds per 30 feet of bed row. As with the previous experiments, all soil disinfestation treatments provided better weed control than the untreated control, but none of them differed significantly from each other (table 2).

The predominant weeds were subjected to analysis of variance separately. Results showed that the control 
of cheeseweed was improved by all soil disinfestation treatments by about $50 \%$ over the control. All other annual weeds, including yellow blossom sweetclover (Melilotus officinalis), chickweed, annual bluegrass, shepherdspurse, crabgrass and spotted spurge (Euphorbia maculata), were reduced by nearly $100 \%$ by the various treatments. None of the treatments provided satisfactory control of yellow nutsedge (Cyperus esculentus).

\section{Marketable yield of strawberries}

Experiment A. Yield data was taken twice weekly for 12 weeks in experiment A, 3 weeks during the short fall season, then 9 weeks in the spring. As the harvest data was collected, it became apparent that as air temperatures increased in late May and June, production dropped off and the differences in yield among the different soil treatments became less marked and more variable. Over the entire season, increases in marketable yields from the soil treatments ranged from $32 \%$ to $42 \%(P<0.08)$, as compared with the untreated control. As with the weed management data, no differences among the five solarization or fumigation treatments were found. Apart from weed growth, the only apparent pest problem during strawberry production was root damage caused by the feeding of Hoplia callipyge beetle grubs, which occurred in the untreated control plots only. Care was taken during harvest to select strips from untreated control plots that were not affected by the insect-feeding damage.

Experiment B. Berries were harvested twice weekly for 11 harvests in experiment B. Total yield per plot was taken and culls separated out for marketable yields. As opposed to experiment A, significant differences in yield $(P<0.05)$ were observed among some of the treatments (table 2). Soil disinfestation treatments increased berry yields $21 \%$ to $55 \%$ over the untreated control. Solarization with the plastic film left in place as a mulch during plant growth resulted in the highest marketable berry yield.

However, yields following metam sodium application plus solarization were not different from the untreated control (table 2). Most of the higher yields resulted from the first five harvests. The yield results are somewhat different from those of experiment A, and may have resulted from the solarization process starting about 4 weeks later in the year and resulting in fewer solarization heat units. In addition, the harvest season was terminated at least a week early because of an unseasonable hailstorm in June.

\section{Benefits to users}

The results of the KREC field study with parsley, along with the two onfarm experiments with strawberry, showed that solarization is an efficacious weed control option for fall/ spring specialty and organic crops in the San Joaquin Valley. Also, there are economic advantages to using solarization: the $\$ 150$ to $\$ 300$ per acre cost of using solarization (row application) is much cheaper than methyl bromide fumigation. End users should be aware that certain weeds, such as yellow and purple nutsedge (C. rotundus), are not consistently controlled by solarization.

The advantages of solarization include ease of use by the grower, relatively low treatment costs, and no hazards to the grower, workers or public, which is important at the urbanagricultural interface. Solarization is acceptable for use in organic production, and no permits or pesticide reporting is required. As an option, the film can be kept in place after treatment as a bed mulch to improve the cost/benefit ratio.

On the other hand, disadvantages include the unavailability of land for 3 to 4 weeks during the summer, and maintenance of the plastic (patching holes when necessary). Solarization must be timed soon after the spring harvest is completed but before planting for the next crop. Furthermore, little expert consultation is available (as opposed to chemical pesticide representatives). Combining solarization with chemical fumigants such as metam sodium is another attractive option for commercial users, but may be no more effective and cost more than solarization alone.

\section{J.J. Stapleton is Integrated Pest Manage-} ment Plant Pathologist, UC Statewide IPM Program, UC Kearney Agricultural Center (KAC); R.H. Molinar is Small Farms Advisor, UC Cooperative Extension, Fresno County; K. Lynn-Patterson is GIS Analyst, and S.K. McFeeters is GIS Assistant, Geographic Information Systems Facility, KAC; and A. Shrestha is Integrated Pest Management Weed Ecologist, UC Statewide IPM Program, KAC. We thank Michael Yang, Ruth Dahlquist, Carol Adams and Husein Ajwa for technical assistance with aspects of these studies; growers Touxia Thaoxachay and Howard Yang for their cooperation; and Trical for the methyl bromide/chloropicrin application. This work was supported, in part, by grants from the UC IPM Research Grants Program, the UC Center for Pest Management Research and Education, and the California Strawberry Commission. We respectfully dedicate this report to the memory of Carol Adams, Principal Statistician, UC Riverside.

\section{References}

Carter CA, Chalfant JA, Goodhue RE, McKee GJ. 2005. Costs of 2001 methyl bromide rules estimated for California strawberry industry. Cal Ag 59:41-6.

[CDFA] California Department of Food and Agriculture. 2002. State organic crop and acreage report. California Organic Inspection Services. www.cdfa.ca.gov/is/fveqc/ organic.htm.

Elmore CL, Roncaroni JA, Giraud DD. 1993. Perennial weeds respond to control by soil solarization. Cal Ag 47(1):19-22.

Stapleton JJ. 2000. Soil solarization in various agricultural production systems. Crop Protect 19:837-41.

Stapleton JJ, Elmore CL, DeVay JE. 2000. Solarization and biofumigation help disinfest soil. Cal Ag 54(6):42-5.

Stapleton JJ, Prather TS, Dahlquist RM. 2000. Implementation and validation of a thermal death database to predict efficacy of soil solarization for weed management in California. UC Plant Protect Quarterly 10(3):9-10. www.uckac.edu/ppq.

Stapleton JJ, Prather TS, Mallek SB, et al. 2002. High temperature solarization for production of weed-free container soils and potting mixes. HortTech 12:697-700.

[USDA] US Department of Agriculture. 2004. 2002 Census of Agriculture. National Agricultural Statistics Service. www.nass.usda.gov/census. 